\title{
Cytotoxic activity of the neurotoxin anatoxin-a on fish leukocytes in vitro and in vivo studies
}

\author{
Anna Rymuszka \\ Department of Physiology and Ecotoxicology, Institute of Biotechnology, John Paul II \\ Catholic University of Lublin, Poland \\ Received December 3, 2010 \\ Accepted March 7, 2012
}

\begin{abstract}
The aim of this study was to investigate the potential cytotoxic effects of different concentrations $(0.01,0.025,0.05,0.1$ and $1 \mu \mathrm{g} / \mathrm{ml}$ medium $)$ of pure anatoxin-a on carp immune cells (in vitro study). Furthermore, changes in the cell immune functions isolated from 10 carp exposed by immersion to anatoxin-a $(25 \mu \mathrm{g} / \mathrm{l})$ for 5 days have been examined. Cytotoxicity of the toxin to leukocytes was determined by measuring intracellular adenosine triphosphate and glutathione concentrations. Lymphocyte proliferation was determined by measurement of bromodeoxyuridine incorporation during DNA synthesis. The phagocytes were assayed for intracellular production of reactive oxygen species. The in vitro results showed that pure toxin induced adverse effects on immune cells only after application of the higher concentrations $(0.05$, 0.1 and $1 \mu \mathrm{g} / \mathrm{ml})$. Phagocytes exposed to anatoxin-a exhibited a significant $(P<0.05)$ reduction in glutathione concentration. The lymphocyte proliferation was decreased by the toxin, and B cells were more sensitive than T cells. The present study showed for the first time that anatoxin-a administered to fish by immersion, had suppressive effects on lymphocyte proliferation and the antioxidant potential of phagocytes.
\end{abstract}

Cyanotoxin, lymphocytes, phagocytes, immunotoxicity, common carp

Cyanobacteria are a source of bioactive toxic compounds known as cyanotoxins that may cause potential stress and hazard to the health of aquatic animals. Anatoxin-a (Antx-a) is a low molecular weight alkaloid $(165 \mathrm{Da})$ of neurotoxic activity. It is a bicyclic secondary amine, 2-acetyl-9-azabicyclo [4.2.1] non-2-ene, produced mainly by Anabaena flos-aquae or Anabaena planktonica, but also by Aphanizomenon, Cylindrospermopsis, Microcystis species and benthic Oscillatoria (Osswald et al. 2009). Occurrence of toxic blooms containing Antx-a has been reported in North America, Asia, Africa and Europe (among others in Poland) (Park et al. 1998; Sivonen and Jones 1999; Krienitz et al. 2003; Viaggiu et al. 2004; Pawlik-Skowrońska et al. 2004). The highest concentrations of the toxin found in environmental cyanobacterial samples, expressed as the sum of the toxin in the cyanobacteria cells and in the water were detected in the USA $(1750 \mu \mathrm{g} / \mathrm{l})$ and in German lakes and reservoirs (13.1 $\mu \mathrm{g} / \mathrm{l})$ (Bumke-Vogt et al. 1999; Hedman et al. 2008). Antx-a is one of the most active compounds produced by cyanobacteria, toxic to terrestrial organisms, including cattle, dogs and birds (Edwards et al. 1992; Krienitz et al. 2003; Gugger et al. 2005). For Antx-a the i.p. LD $_{50}$ for mice ranges from $250 \mu \mathrm{g} / \mathrm{kg}$ to $375 \mu \mathrm{g} / \mathrm{kg}$ (Rogers et al. 2005).

Antx-a binds to cholinergic nicotinic receptors and acts as acetylcholine but is not hydrolyzed by cholinesterase causing persistent stimulation and blockage of further electrical transmission. Consequently, the toxin disrupts skeletal and respiratory muscle functions and in high doses causes death due to respiratory arrest (Sivonen and Jones 1999). The cholinergic nicotinic receptors are common in vertebrates, also in fish (Zirger et al. 2003).

In comparison to other cyanotoxins, e.g. microcystins or nodularin, less information on the effects of Antx-a on fish is available. Only limited laboratory observations performed on

Address for correspondence:

Dr. Anna Rymuszka

Department of Physiology and Ecotoxicology, Institute of Biotechnology

John Paul II Catholic University of Lublin

14 Al. Racławickie str, 20-950 Lublin, Poland

Phone: +48815333784

Fax: +48 815367089

E-mail: anrym@kul.lublin.pl

http://actavet.vfu.cz/ 
juvenile carp, goldfish and zebrafish reported adverse effects of the toxin such as temporary alterations in heart rates, disorders of swimming and increased mortality (summarised by Osswald et al. 2007b). In the environment, common carp (Cyprinus carpio L) can consume colonies and filaments of cyanobacteria as well as cyanotoxin contaminated food (e.g. phytoplankton, zooplankton) or they can directly absorb the dissolved toxin through gills or skin. Experimental studies by Osswald et al. (2007a) showed that juvenile carp may accumulate Antx-a. The authors found that the toxin can reach a value of $0.768 \mu \mathrm{g} / \mathrm{g}$ of dry weight in the whole fish. To our knowledge there is a lack of research on the effects of Antx-a on the fish immune system. Therefore, the aim of this research was to study the in vivo and in vitro effects of the toxin on selected functions of immune cells isolated from blood and pronephros of carp.

\section{Materials and Methods}

\section{Experimental animals}

Pure Antx-a was purchased from TOCRIS Bioscience, USA. A stock solution of $1 \mathrm{mg} / \mathrm{ml}$ in PBS (Biomed, Lublin, Poland) was prepared and kept at $-20{ }^{\circ} \mathrm{C}$. The experiments were carried out in accordance with the guidelines for the care of laboratory animals (Local Committee of Ethics, approval number 9/2009). Common carp weighing about 300-350 g (approximately 2 years old), were obtained from a commercial farm. Fish were maintained in recirculating water at a temperature of $18{ }^{\circ} \mathrm{C}$ on a $8 / 16 \mathrm{~h} \mathrm{light} /$ dark cycle in 801 tanks. The fish were acclimatised for 1 week prior to use in the experiments. Only healthy fish without signs of overt infection or disease were used in the studies.

\section{In vivo exposure}

Fish were divided into two groups (control and experimental) and transferred to tanks without continuous system of water filtration. Each group consisted of five individuals. Experimental fish were exposed by immersion to pure Antx-a at the concentration of $25 \mu \mathrm{g} / 1$ for 5 days. Since Antx-a is not stable in water $(50 \%$ reduction after several hours to days) (Osswald et al. 2007b), water was changed and toxin was applied de novo daily. Following exposure, fish were euthanized with $0.2 \%$ Propiscin (active substance etomidate, Żabieniec, Poland) diluted in water. The blood and pronephros were taken aseptically. Then the immune cells were isolated and the assays were carried out. The effects of in vivo exposure to the toxin on the immune indicators were compared to the response of the cells isolated from the control fish.

\section{In vitro experiment}

The in vitro study was performed on the cells obtained from 10 common carp. Animals were euthanized with $0.2 \%$ Propiscin and immune cells were isolated from blood and pronephros. Afterwards, the toxin was added to the cell suspension. Final concentrations of the Antx-a $(0.01,0.025,0.05,0.1$ and $1 \mu \mathrm{g} / \mathrm{ml})$ were obtained by diluting the stock solution with PBS.

\section{Cell isolation}

Cell suspension from head kidney was obtained by passing the tissue through a nylon mesh $(100 \mu \mathrm{m}$, Sigma, Aldrich, USA) with PBS without $\mathrm{Ca}^{2+}$ and $\mathrm{Mg}^{2+}$ (Biomed, Lublin, Poland) supplemented with $0.2 \%$ heparin (Polfa, Warsaw, Poland). Blood samples were taken immediately by caudal vein puncture; then blood was diluted 1:1 with PBS without $\mathrm{Ca}^{2+}$ and $\mathrm{Mg}^{2+}$. Blood and pronephros cell suspensions were layered on Gradisol (AquaMedica, Poland) density gradient (1.115 g/ml for the separation of phagocytes; mainly monocytes, neutrophiles from blood and macrophages from pronephros and $1.06 \mathrm{~g} / \mathrm{ml}$ for the separation of lymphocytes). Following 30 min centrifugation at $450 \times g$, the cell fractions were collected and washed three times with PBS without $\mathrm{Ca}^{2+}$ and $\mathrm{Mg}^{2+}$. Cell suspensions showed $95 \%$ purity and over $98 \%$ of the leukocytes were viable, as determined by trypan blue exclusions. The cells were cultured in RPMI-1640 (Lonza, Belgium) supplemented with $10 \%$ of foetal bovine serum (FCS, Gibco, UK), $100 \mathrm{U} / \mathrm{ml}$ of penicillin and $100 \mathrm{mg} / \mathrm{ml}$ of streptomycin.

\section{The ATP assay}

The ATP assay (CellTiter-Glo ${ }^{\circ}$ Luminescent Cell Viability Assay) determines concentration of cellular ATP as an indirect measure of cell viability. According to the manufacturer's protocol (Promega, USA), $100 \mu 1$ of the cell suspension $\left(1 \times 10^{6} \mathrm{cell} / \mathrm{ml}\right)$ were placed on 96-well plates. In the in vivo study the cells obtained from the control and experimental fish after Antx-a intoxication were incubated overnight at room temperature. In the in vitro examinations various Antx-a concentrations $(0.01,0.025,0.05,0.1$ and $1 \mu \mathrm{g} / \mathrm{ml})$ were added to the cell suspensions and incubated overnight at room temperature. The reduction of cell viability was expressed as percentage reduction of luminescence emitted in the presence of the test compound in comparison with the toxin-free control group.

\section{Reactive oxygen species (ROS) production assay}

Phagocytic leukocytes when stimulated with phorbol 12-myristate 13-acetate (PMA) display a respiratory burst and produce superoxide anions, one of the ROS. Production of intracellular superoxide anions was determined by 
the nitroblue tetrazolium (NBT) reduction assay. The phagocytic cells were preincubated for $24 \mathrm{~h}$ with different concentrations of Antx-a from 0.01 to $1 \mu \mathrm{g} / \mathrm{ml}$ at room temperature. Then the toxin was removed and cells were incubated with $0.1 \%$ NBT (POCh, Poland) solution containing $1 \mu \mathrm{g} / \mathrm{ml}$ of PMA (Sigma, Aldrich). Following $1 \mathrm{~h}$ incubation the reaction was stopped with absolute methanol. The reduced NBT (in the form of formazan) was dissolved with $120 \mu \mathrm{l}$ of $2 \mathrm{M}$ potassium hydroxide $(\mathrm{KOH}, \mathrm{POCh}$, Poland) and $100 \mu \mathrm{l}$ of dimethyl sulphoxide (DMSO, POCh, Poland) per well and the colour was subsequently measured at $630 \mathrm{~nm}$ with a spectrophotometer (BioRad 550).

Glutathione assay

A luminescence-based GSH-Glo Assay (Promega, Madison, WI, USA) was used for quantification of glutathione in fish leukocytes according to the manufacturer's recommendation.

Lymphocyte proliferation

Lymphocytes $\left(1 \times 10^{6}\right.$ cells $\left./ \mathrm{ml}\right)$ were suspended in RPMI-1640 medium and distributed into a 96-well microtitre plate. In the in vitro studies the cells were incubated with the used concentrations of Antx-a. A concanavalin A (ConA, $50 \mu \mathrm{g} / \mathrm{ml}$; Sigma, Aldrich) as a T cell mitogen or lipopolysaccharide from Serratia marcescens (LPS, $10 \mathrm{mg} / \mathrm{ml}$; Sigma, Aldrich) as a B cell mitogen was added to the cell suspension and incubated for $72 \mathrm{~h}$ at $20{ }^{\circ} \mathrm{C}$. Proliferation of $\mathrm{T}$ and $\mathrm{B}$ lymphocytes was determined as a response to ConA and LPS, respectively. Cell proliferation assays were performed using the BrdU-incorporation assay (Cell Proliferation ELISA, Roche Applied Science, Switzerland) according to the kit protocol. Stimulation Index (SI) was determined by comparing mitogen stimulated cells to unstimulated (mitogen-free) cells.

\section{Statistical analysis}

Data were analysed statistically by one-way analysis of variance (ANOVA). When significant differences were detected, Duncan's test was used to compare the experimental groups to control. Statistical evaluation of the results was performed using the computer program Statistica 8.0 (StatSoft, Tulsa, USA). Significance was determined at $P<0.05$.

\section{Results}

\section{Cytotoxicity induced by exposure to Antx-a}

Using the bioluminescent assay determining the amount of ATP, we measured the potential cytotoxicity of the toxin. Immune cells isolated from blood and pronephros exposed both in vitro (Fig. 1) and in vivo (data not illustrated) to the toxin did not show significantly decreased ATP levels. When the cells were exposed to Antx-a at the concentration of $1 \mu \mathrm{g} / \mathrm{ml}$, the level of ATP in the cells was decreased at approximately $10 \%$ which suggests that the toxin slightly affected cell viability.

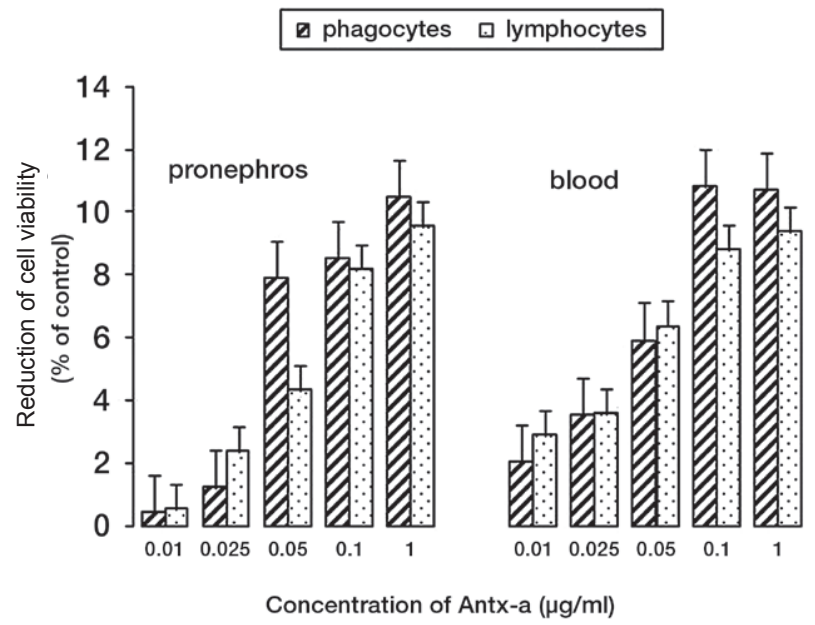

Fig. 1. In vitro effects of Antx-a on pronephros and blood phagocyte and lymphocyte viability. Viability of the cells was determined by the amount of ATP in the viable cells and calculated as reduction of exposed cells relative to unexposed cells (a negative control). Values exhibit mean $\pm \mathrm{SD}, \mathrm{n}=10$, *differences significant at $P<0.05$ 


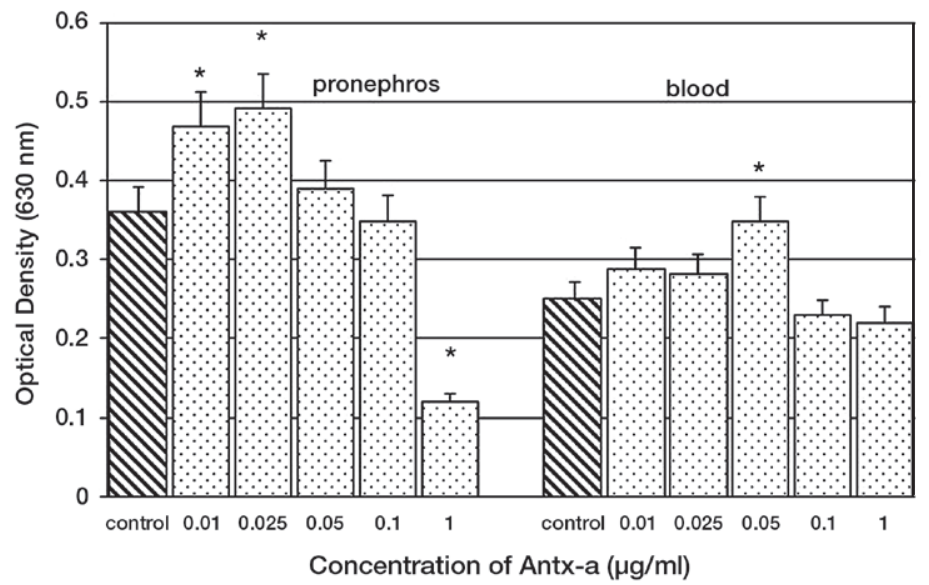

Fig. 2. The in vitro influence of Antx-a on respiratory burst activity of carp pronephros and blood phagocytes (mean $\pm \mathrm{SD}, \mathrm{n}=10),{ }^{*}$ differences significant at $P<0.05$

\section{Effect of toxin on reactive oxygen species production}

In vitro exposure of pronephros phagocytes to Antx-a at 0.01 and $0.025 \mu \mathrm{g} / \mathrm{ml}$ for $24 \mathrm{~h}$ caused significant $(P>0.05)$ increase in production of reactive oxygen species (Fig. 2$)$. However, the toxin at the concentration of $1 \mu \mathrm{g} / \mathrm{ml}$ caused a decrease of the respiratory burst activity of the exposed cells compared to the control group. Similary, after incubation with the toxin at $0.05 \mathrm{mg} / \mathrm{ml}$, increased ROS production in blood phagocytes was seen. In contrast to the results obtained on pronephros cells, no significant changes in the PMAstimulated blood phagocytes were apparent at the other used concentrations. Moreover, fish exposed in vivo to the toxin showed significantly higher respiratory burst activity in pronephros leukocytes compared to control fish (Fig. 3). However, in leukocytes isolated from blood no effects of the toxin on ROS production were noted.

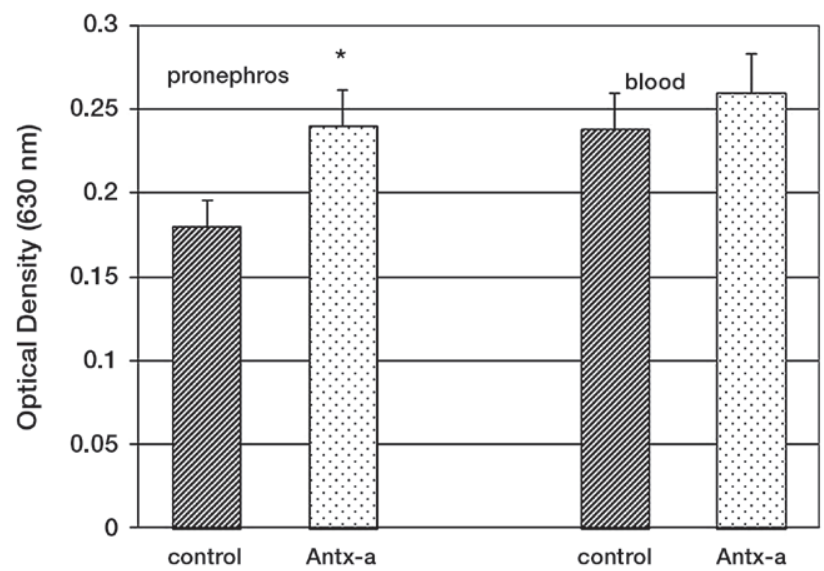

Fig. 3. Respiratory burst activity (RBA) in pronephros and blood carp cells exposed to pure Antx-a (25 $\mu \mathrm{g} / \mathrm{l})$. Result are expressed as the mean of quadruplicate readings from 5 fish (mean $\pm \mathrm{SD}, \mathrm{n}=5)$. *Data represent a significant difference between the exposed and the control group $(P<0.05)$ 


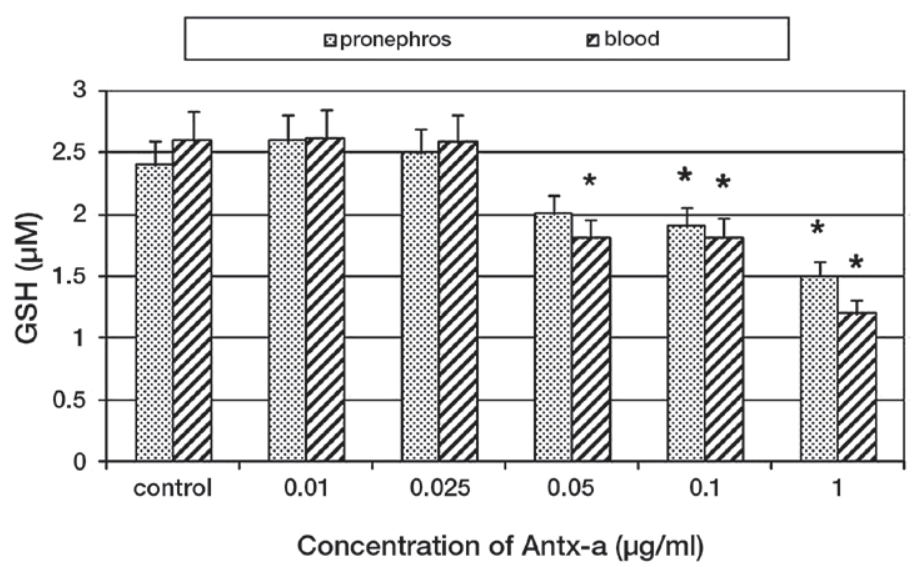

Fig. 4. In vitro effects of Antx-a on a total cellular glutathione (GSH) level in carp pronephros and blood phagocytes (mean $\pm \mathrm{SD}, \mathrm{n}=10),{ }^{*}$ differences significant at $P<0.05$

\section{Effect of toxin on GSH level}

As shown in Fig. 4, Antx-a decreased significantly $(P<0.05)$ the total cellular glutathione level in fish phagocytes at the higher used concentrations $(0.05,0.1$ and $1 \mu \mathrm{g} / \mathrm{ml})$. Moreover, in vivo studies showed reduction of this indicator in the cells isolated from pronephros and blood (decrease of $38.5 \%$ and $55.5 \%$ compared to the control, respectively) (Fig. 5).

\section{Effect of toxin on lymphocyte proliferation}

The reactivity of lymphocytes, stimulated by mitogens (ConA or LPS) was analysed by measurement of BrdU incorporation during DNA synthesis in proliferating cells. After administration of the toxin at the highest used concentration $(1 \mu \mathrm{g} / \mathrm{ml})$, suppression of $\mathrm{T}$ and B lymphocyte proliferation was seen (Fig. 6). Similarly, blood lymphocytes showed significantly decreased proliferation after the toxin application at the concentration of $1 \mu \mathrm{g} / \mathrm{ml}$. The DNA synthesis in proliferating B cells isolated from blood and pronephros

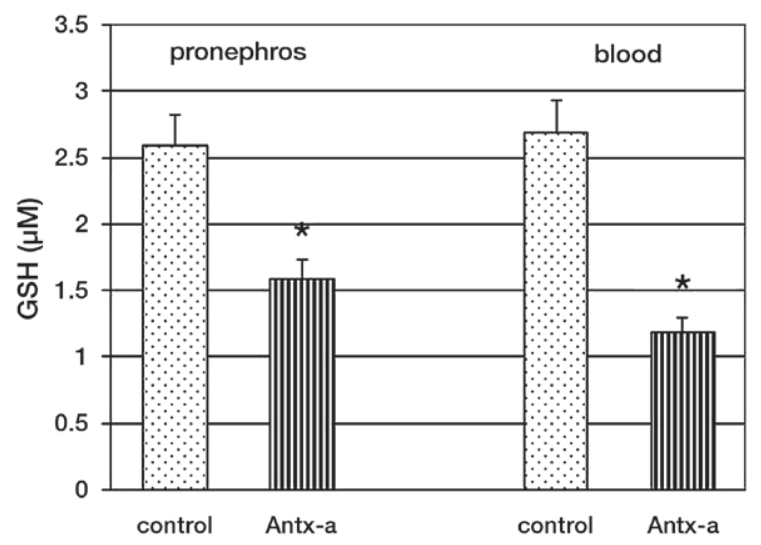

Fig. 5. Contents of total cellular glutathione (GSH) in the cells isolated from carp blood and pronephros after 5 days exposure to pure Antx- a $(25 \mu \mathrm{g} / \mathrm{l})$. Results are expressed as the mean of quadruplicate readings from 5 fish $($ mean $\pm \mathrm{SD}, \mathrm{n}=5)$. $*$ Data represent significant differences between the exposed and the control group $(P<0.05)$ 


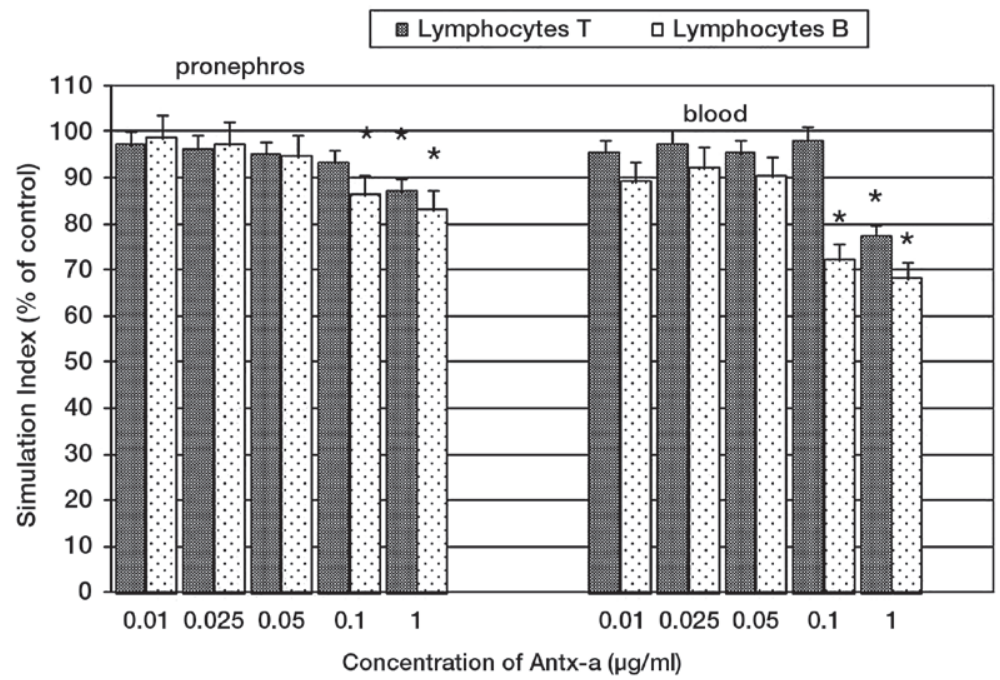

Fig. 6. In vitro effects of Antx-a on proliferation of T and B lymphocytes isolated from carp blood and pronephros, expressed as a Stimulation Index, after $72 \mathrm{~h}$ exposure to various concentrations of Antx-a. Data are shown as mean $\pm \mathrm{SD}, \mathrm{n}=10, *$ differences significant at $P<0.05$

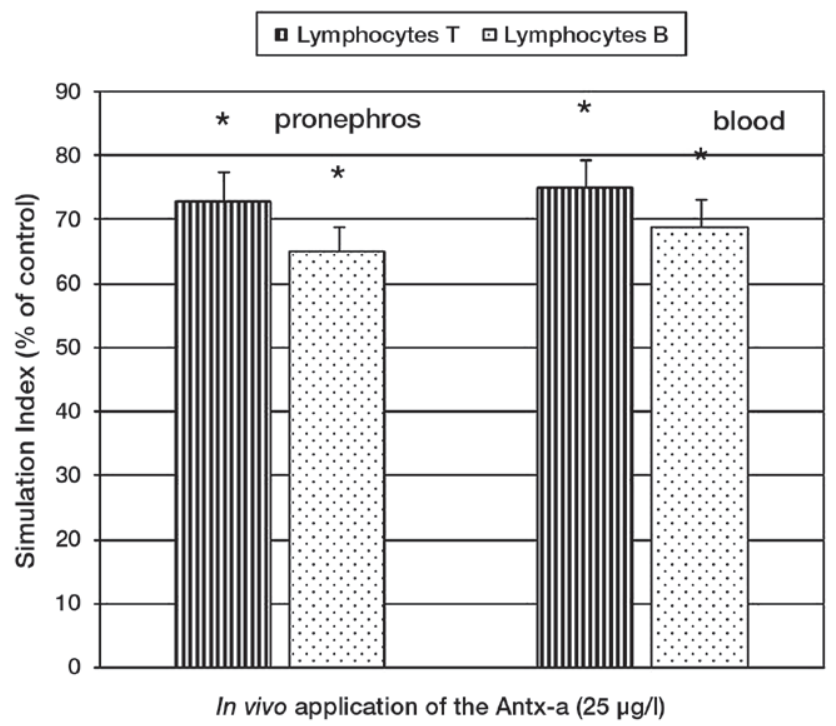

Fig. 7. Proliferation of $\mathrm{T}$ and $\mathrm{B}$ lymphocytes isolated from carp blood and pronephros from fish exposed to pure Antx-a $(25 \mu \mathrm{g} / \mathrm{l})$ for 5 days, assessed by DNA fragmentation. Result are expressed as a Stimulation Index of quadruplicate readings from 5 fish (mean $\pm \mathrm{SD}, \mathrm{n}=5)$, *data represent a significant difference between the exposed and the control group $(P<0.05)$

was significantly decreased by the toxin at the concentration of $0.1 \mu \mathrm{g} / \mathrm{ml}$ compared to the control group. Moreover, after 5 days of intoxication with Antx-a, lymphocyte proliferation occurred to be significantly $(P<0.05)$ reduced (Fig. 7). 


\section{Discussion}

In our study we found no close relationship between ATP levels and functions of the cells after exposure to higher Antx-a concentrations. The results showed that lymphocyte viability was not affected at $0.1 \mu \mathrm{g} / \mathrm{ml}$ of Antx-a (Fig.1); however, a significant decrease of B cell proliferation was observed (Fig. 6).

Interestingly, Antx-a at low concentrations may lead to an increase of the respiratory burst activity in the pronephros leukocytes but higher concentrations inhibit this process (Fig. 2). Apparently, stimulatory responses to low concentrations of the toxin under shortterm exposure may be a primary protective response of cells against stress; however, higher concentrations are immunotoxic. This observation is in agreement with the conclusion reviewed by Tort (2011). When the stressor is acute and short-term, the response pattern is stimulatory. In contrast, chronic stress may result in suppression of fish immune function.

Glutathione system plays an important role in the antioxidant defense in animal cells. Exposure to Antx-a caused a significant $(P<0.05)$ reduction in GSH level in immune cells (Figs 4 and 5). These results suggest that the toxin reduced the antioxidant potential of the cells, thereby increasing cell susceptibility to oxidative damage.

Dysregulation of cellular antioxidant defense systems may be a potential mechanism by which Antx-a affects immune responses. It is well known that reactive oxygen species and oxidative stress are involved in pesticide immunotoxicity (Harford et al. 2005). Similary, the changes observed after stress induced by cyanotoxin increasing the intracellular production of $\mathrm{H}_{2} \mathrm{O}_{2}$ and other ROS, leading to alterations in cell signaling pathways involved in cell growth and cell death. This agrees with our recent studies showing that Antx-a affects generation of superoxide radicals and nitrate formation and induces apoptosis in fish immune cells (Rymuszka and Sierosławska 2010, 2011). Moreover, it has been reported that the toxin can cause apoptosis in rat thymocytes and monkey kidney cells, mediated by generation of reactive oxygen species and caspase activation (Rao et al. 2002). On the other hand, Teneva et al. (2005) demonstrated that cytotoxic effects of Antx-a on mouse T and B lymphocytes were not induced by apoptosis.

Direct exposure of fish to the toxin even at low concentrations can cause a stress response. We can assume that the immersion of fish in cyanotoxin caused not only significant $(P<0.05)$ changes in lymphocyte proliferation (Fig. 7) but perhaps other essential immune cell functions, e.g. cytokine production, thus influencing the immune responses.

The above data allowed us to conclude that Antx-a affects the fish immune cell functions. However, this research needs to be expanded for more details on the mechanisms of immunotoxic activity.

\section{Acknowledgments}

This research was supported by the Ministry of Science and Higher Education, Grant no. NN303606138.

\section{References}

Bumke-Vogt C, Mailahn W, Chorus I 1999: Anatoxin-a and neurotoxic cyanobacteria in German lakes and reservoirs. Environ Toxicol 14: 117-125

Edwards C, Beattie KA, Scrimgeour CM, Codd GA 1992: Identification of anatoxin-a in benthic cyanobacteria (blue-green algae) and in associated dog poisonings at Loch Insh, Scotland. Toxicon 30: 1165-1175

Gugger M, Lenoir S, Berger C, Ledreux A, Druart JC, Humbert JF, Guette C, Bernard C 2005: First report in a river in France of the benthic cyanobacterium Phormidium favosum producing anatoxin-a associated with dog neurotoxicosis. Toxicon 45: 919-928

Harford A, O'Halloran K, Wright P 2005: The effects of in vitro pesticide exposures on the phagocytic function of four native Australian freshwater fish. Aquat Toxicol 75: 330-342

Hedman CJ, Krick WR, Karner Perkins DA, Harrahy EA, Sonzogni WC 2008: New measurements of cyanobacterial toxins in natural waters using high performance liquid chromatography coupled to tandem mass spectrometry. J Environ Qual 37: 1817-1824 
Krienitz L, Ballot A, Kotut K, Wiegand C, Pütz S, Metcalf JS, Codd GA, Pflugmacher S 2003: Contribution of hot spring cyanobacteria to the mysterious deaths of lesser flamingos at lake Bogoria, Kenya. FEMS Microbiol Ecol 43: 141-148

Osswald J, Carvalho AP, Claro J, Vasconcelos V 2009: Effects of cyanobacterial extracts containing anatoxin-a and of pure anatoxin-a on early developmental stages of carp. Ecotoxicol Environ Saf 72: 473-478

Osswald J, Rellán S, Carvalho AP, Gago A, Vasconcelos V 2007a: Acute effect of anatoxin-a producing cyanobacteria on juvenile fish Cyprinus carpio. Toxicon 49: 693-698

Osswald J, Rellán S, Carvalho AP, Gago A, Vasconcelos V 2007b: Toxicology and detection methods of the alkaloid neurotoxin produced by cyanobacteria, anatoxin-a. Environ Int 33: 1070-1089

Park HD, Kim B, Kim E, Okino T 1998: Hepatotoxic microcystins and neurotoxic anatoxin-a in cyanobacterial blooms from Korean lakes. Environ Toxicol Water Qual 13: 225-234

Pawlik-Skowrońska B, Skowroński T, Pirszel J, Adamczyk A 2004: Relationship between cyanobacterial bloom composition and anatoxin-a and microcystin occurrence in the eutrophic dam reservoir (SE Poland). Pol J Ecol 52: 479-490

Rao PVL, Bhattacharya R, Gupta N, Parida MM, Bhaskar ASB, Dubey R 2002: Involvement of caspase and reactive oxygen specie in cyanobacterial toxin anatoxin-a-induced cytotoxicity and apoptosis in rat thymocytes and Vero cells. Arch Toxicol 76: 227-235

Rogers EH, Hunter ES, Moser VC, Phillips PM, Herkovitz J, Muńoz L, Hall LL, Chernoff N 2005: Potential developmental toxicity of anatoxin-a, a cyanobacterial toxin. J App Toxicol 25: 527-534

Rymuszka A, Sierosławska A 2010: Study on apoptotic effects of neurotoxin anatoxin-a on fish immune cells. Neuroendocrinol Lett 31: 11-15

Rymuszka A, Sierosławska A 2011: Effects of neurotoxin - anatoxin-a on common carp (Cyprinus carpio L.) innate immune cells in vitro. Neuroendocrinol Lett 32: 84-88

Sivonen K, Jones G 1999: Cyanobacterial toxins. In: Chorus I (Ed.): Cyanotoxins occurrence, causes and consequences. Springer-Verlag, Germany, pp. 41-111

Teneva I, Mladenov R, Popov N, Dzhambazov B 2005: Cytotoxicity and apoptotic effects of microcystin-LR and anatoxin-a in mouse lymphocytes. Folia Biol (Praha) 51: 62-67

Tort L 2011: Stress and immune modulation in fish. Dev Comp Immunol 35: 1366-1375

Viaggiu E, Melchiorre S, Volpi F, Di Corcia A, Mancini R, Garibaldi L, Crichigno G, Bruno M 2004: Anatoxin a toxin in the cyanobacterium Planktothrix rubescens from a fishing pond in northern Italy. Environ Toxicol 19: 191-197

Zirger JM, Beattie CE, Mckay DB, Boyd RT 2003: Cloning and expression of zebrafish neuronal nicotinic acetylcholine receptors. Gene Expr Patterns 3: 747-754 